\title{
The state of occupational dermatoses in Turkey
}

\section{Türkiye'de mesleki dermatozların durumu}

\section{๑ Șafak Metekoğlu, ๑ Mehmet Melikoğlu*, ๑ Semih Güder**, ๑ Illteriș Oğuz Topal***}

İstanbul University Faculty of Medicine, Beyazıt Medico-Social Center, Clinic of Dermatology, İstanbul, Turkey

*Atatürk University Faculty of Medicine, Department of Dermatology, Erzurum, Turkey

**istanbul Occupational Diseases Hospital, Clinic of Dermatology, İstanbul, Turkey

***istanbul Okmeydanı Training and Research Hospital, Clinic of Dermatology, İstanbul, Turkey

\begin{abstract}
Due to the difficulties in diagnosing occupational diseases and deficiencies in statistical data, occupational diseases are underreported in Turkey. The average number of records in our country is around 10, when at least 100.000 new occupational skin diseases need to be diagnosed annually. This is due to the shortcomings in the diagnosis and notification of the occupational diseases in our country. In this article, we analyzed occupational skin diseases and their International Classification of Diseases codes, and how they are diagnosed medically and legally, and the difficulties in diagnosing these diseases. The article emphasizes that the dermatologists should be trained in occupational diseases and occupational health codes in order to improve diagnosing and reporting occupational diseases.

Keywords: Occupational skin diseases, occupational dermatoses, occupational diseases

Öz

Ülkemizde mesleki hastalıkların tanı aşamasındaki zorluklar ve istatistiklerdeki yetersizlikler nedeniyle, meslek hastalıklarına olması gerektiğinden çok daha az tanı konulabilmektedir. Ülkemizde yılda en az 100.000 yeni mesleki deri hastalığının tanı alması gerekirken kayıtlara geçen sayı ortalama 10 civarındadır. Bu durum ülkemizde meslek hastalığı tanısı ve bildirimi aşamalarındaki eksikliklerden kaynaklanmaktadır. Bu yazıda mesleki deri hastalıklarının ve International Classification of Diseases kodlarının neler olduğu, bu hastalıklara nasıl tıbbi ve yasal tanı konulduğu, tanı aşamasında ne gibi zorluklar yaşandığı incelenerek, dermatoloji uzmanlarının mesleki hastalıklar ile ilgili kanunlar hakkında bilgilendirilmesinin tanı sürecine katkısı vurgulanmıştır.

Anahtar Kelimeler: Mesleki deri hastalıkları, mesleki dermatozlar, mesleki hastalıklar
\end{abstract}

\section{Legal definition of occupational disease}

According to Article 14 of Social Security and Universal Health Insurance Law No. 5510 published in 2008, occupational disease legally refers to the temporary or permanent disease, physical or mental handicapped status, caused by a reason reiterated due to the quality of the work made or worked by the insurance holder or by the working conditions. It is obligatory to communicate the occupational diseases according to Article 28 of Social Security Instutition (SSI) Law No. 506

Frequency of occupational diseases in Europe and Turkey

Statistical Office of the European Communities (EUROSTAT) determined that the rate of occupational diseases based on declaration in Europe (EU) countries reached up to $8.6 \%$

Address for Correspondence/Yazışma Adresi: Şafak Metekoğlu MD, İstanbul University Faculty of Medicine, Beyazıt Medico-Social Center, Clinic of Dermatology, İstanbul, Turkey Phone: +90 5335188017 E-mail: cilthastaliklari@gmail.com Received/Geliş Tarihi: 19.04.2017 Accepted/Kabul Tarihi: 09.04.2018 ORCID ID: orcid.org/0000-0003-0849-2698 
in working population aged 15 to 64 years in 20071 . In our country, Turkish Statistical Institute determined that more than 3\% and 2\% of the persons employed in and before 2007 and 2013, respectively, suffered from an occupational disease in the past year. While the annual number of occupational diseases should be expressed in hundreds of thousands in our country, the insufficient recognition system for occupational diseases and inadequate coverage of the issue in undergraduate education of physicians lead to problems in diagnosis and recording of these diseases. Given the fact that the incidence of occupational diseases in working population ranges between 4 and 12 per thousand according to the data of the International Labour Organisation (ILO), it can be concluded that 100.000 to 300.000 workers suffer from an occupational disease annually in Turkey. Considering the long average working hours and the high prevalence of insecure and flexible working conditions in Turkey, it is more likely that the expected annual number of occupational diseases would be about 300.0002,3. According to data from 2013, there were 351 individuals in Turkey for whom an occupational disease was reported, while the relevant number was more than 40.000 in $2013^{4}$. Data of the Ministry of Labour and Social Security show that the legal diagnosis of an occupational disease could be made only in 395 workers in 2012 . These figures cover the cases for which the judicial process has been finalised. Data obtained from the occupational diseases hospitals for cases for which the medical diagnosis process has been completed indicate that the diagnosis of occupational diseases could be made in 3388 of 6792 referrals in 2008². National Occupational Health and Safety Policy Document covering the period between 2009 and 2013 indicates that the occupational diseases could not be recognised. For the period covered by the document, the goal was stated as "to increase the detection rate of cases of expected but unrecognised occupational diseases by $500 \%{ }^{\prime \prime}$. However, the rates were unfortunately far below this goal according to the data for the period 2012-2015. Table 1 provides the distribution by years for cases of occupational diseases legally diagnosed by the Social Security Institution (SSI).

\section{Definition of occupational skin disease}

Occupational skin disease is defined as any pathology of the skin for which the contribution of occupational exposure has been demonstrated ${ }^{5}$. Occupational skin diseases are among the most commonly observed occupational diseases and hold the second place in incidence after musculoskeletal disorders in EU. Occupational skin diseases account for $10-50 \%$ of all occupational diseases ${ }^{5,6}$. Occupational skin diseases are one of the 5 main groups used when classifying the occupational

Table 1. Occupational diseases diagnosed in the period 2009-2015 in Turkey according to the statistical data of the Social Security Institution

\begin{tabular}{|l|l|}
\hline Years & Number of occupational diseases \\
\hline 2015 & 510 \\
\hline 2014 & 494 \\
\hline 2013 & 351 \\
\hline 2012 & 395 \\
\hline 2011 & 697 \\
\hline 2010 & 533 \\
\hline 2009 & 429 \\
\hline
\end{tabular}

diseases in our country (Table 2$)^{6}$. Contact dermatitis accounts for $90 \%$ of all occupational skin diseases ${ }^{5}$. $80 \%$ of contact dermatitis occur as irritant contact dermatitis and $20 \%$ as allergic contact dermatitis.

Obligation period refers to the longest period of time passed between the actual quitting of the work that caused the occupational disease and the occurrence of the disease of the insurance holder. In some cases, the individual must be exposed to the pathogens in that work for a certain period of time for recognition of the disease as an occupational disease. Exposure time refers to the minimum period of exposure required for insurance legislation to recognise a disease as the occupational disease $\mathrm{e}^{6}$. The obligation period is 5 years for skin cancers and 2 months for non-cancerous skin diseases ${ }^{6}$.

\section{Statistics of occupational skin diseases in our country}

According to statistical data of the SSI for the period 2009-2015 in Turkey, the number of legally diagnosed occupational skin diseases is very limited (Table 3$)^{7}$. Given the fact that the annual average number of occupational diseases has been reported to be about 500 in the period 2009-2015 and, on average, 30\% of these must have been skin diseases, the annual number of occupational skin diseases diagnosed legally must be at least 150 . In addition, as the expected annual number of newly diagnosed occupational diseases in working population of Turkey is 300.000, the annual number of newly diagnosed occupational skin diseases must be minimum 100.000. However, this was reported as low as 17 even in 2011 when the number of occupational diseases diagnosed reached to the maximum.

\begin{tabular}{|c|c|}
\hline Groups & Subgroups and diseases \\
\hline $\begin{array}{l}\text { Group A: Occupational diseases } \\
\text { caused by the chemicals }\end{array}$ & $\begin{array}{l}67 \text { diseases in } 25 \\
\text { subgroups }\end{array}$ \\
\hline Group B: Occupational skin diseases & $\begin{array}{l}\text { Skin cancer and non- } \\
\text { cancerous skin diseases in } \\
2 \text { subgroups }\end{array}$ \\
\hline $\begin{array}{l}\text { Group C: Pneumoconioses and other } \\
\text { occupational respiratory tract diseases }\end{array}$ & 9 diseases in 6 subgroups \\
\hline $\begin{array}{l}\text { Group D: Occupational infectious } \\
\text { diseases }\end{array}$ & 30 diseases in 4 subgroups \\
\hline $\begin{array}{l}\text { Group E: Occupational diseases } \\
\text { caused by physical factors }\end{array}$ & 12 diseases in 7 subgroups \\
\hline
\end{tabular}

Table 3. Number of occupational skin diseases diagnosed in the period 2009-2015 in Turkey according to statistical data of the Social Security Institution

\begin{tabular}{|l|l|l|l|}
\hline & $\begin{array}{l}\text { Skin cancers and } \\
\text { precancerous skin } \\
\text { diseases }\end{array}$ & $\begin{array}{l}\text { Non-cancerous skin } \\
\text { diseases (contact } \\
\text { dermatitis) }\end{array}$ & Total \\
\hline 2015 & 10 & 0 & 10 \\
\hline 2014 & 0 & 6 & 6 \\
\hline 2013 & 0 & 3 & 3 \\
\hline 2012 & 0 & 1 & 1 \\
\hline 2011 & 11 & 6 & 17 \\
\hline 2010 & 0 & 0 & 0 \\
\hline 2009 & 2 & 2 & 4 \\
\hline
\end{tabular}




\section{Diagnostic process of occupational skin diseases in our country}

Differences in classification of occupational diseases (such as "medical diagnosis" and "SSI diagnosis") cause a standardization problem in data. In addition, coverage differences with international institutions, such as EUROSTAT, ILO and WHO, constitute a barrier to gain a clear understanding on the extent of occupational diseases. Unfortunately, more than half of all countries worldwide including our country could not develop modern systems for the diagnosis of occupational diseases ${ }^{6}$.

The list of occupational diseases in Turkey is provided in the appendix of "Regulation on Health Procedures of Social Security Law" (1978) (Table $4)^{6}$. In order get the diagnosis of occupational disease, the employee

\section{Table 4. Occupational skin diseases and the International Classification of Diseases codes}

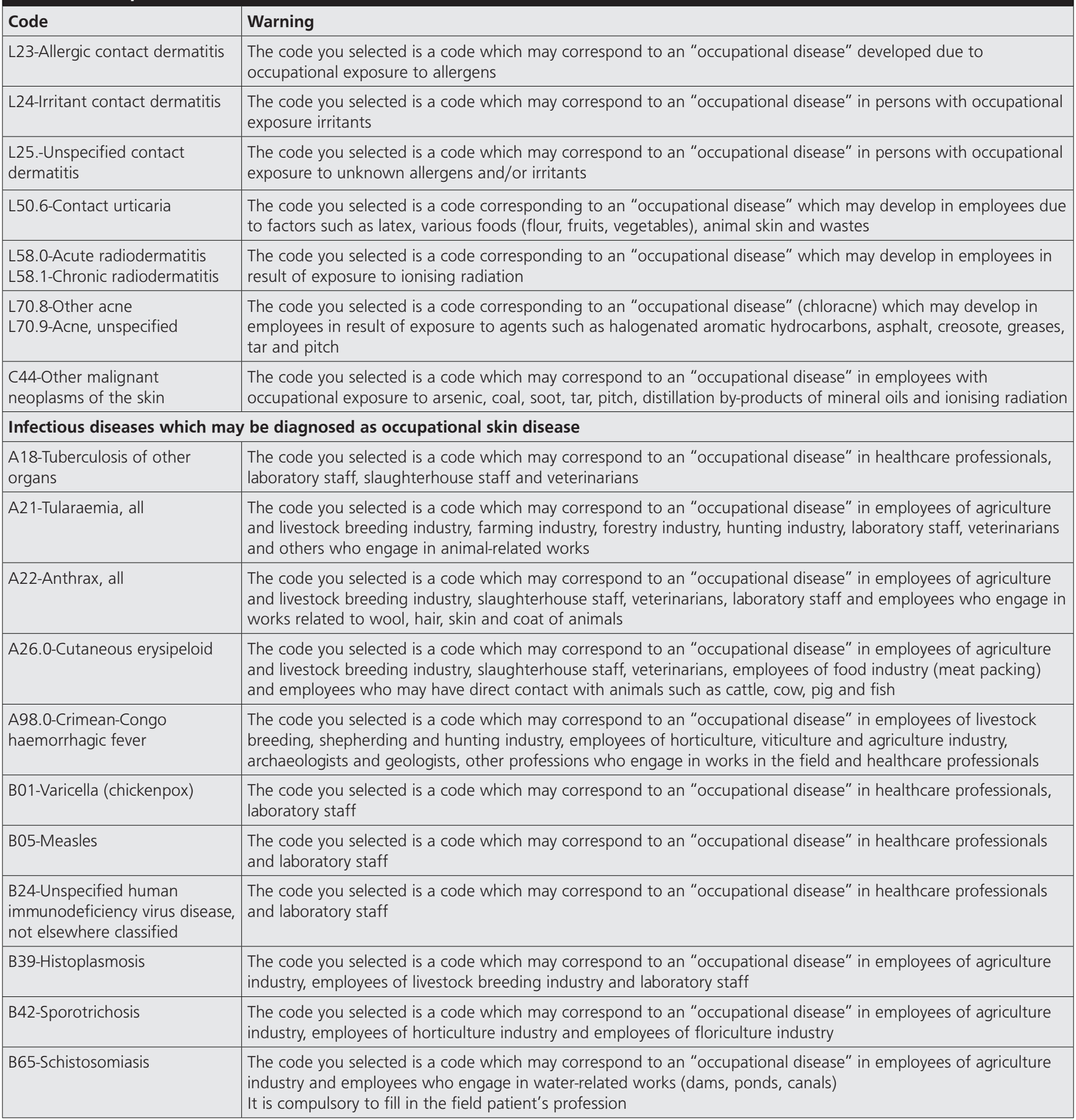


individually applies to the Provincial Directorate of SSI and referral to an authorized hospital is requested. Following the clinical and laboratory investigations and establishment of the association with employment history, the authorized healthcare institution makes the "medical diagnosis". The employee conveys the relevant medical diagnosis to the employer and asks the employer to also apply to SSI. The employer communicates the relevant condition to SSI. Upon completion of the file by the workplace audits, analyses etc., the file is submitted to the SSI Committee of Occupational Disease Diagnosis, and if the file is approved, an incapacity rate is determined. In case this rate exceeds $10 \%$, the employee is entitled for an incapacity benefit and the diagnosis of occupational disease is finalized. Approval of medical diagnosis by the SSI implies the establishment of "legal diagnosis" (Figure 1) ${ }^{8}$. The Ministry of Health has decided that the integration of diagnosis codes of occupational diseases to the information system for the primary care physicians and the software system for public hospitals and training and research hospitals must be completed as of 31.07.2011. According to this integration, when a patient with an occupational disease presents to a physician and the International Classification of Diseases (ICD) codes of the disease are entered into the system, a "notice" will appear on the screen for the code if such diagnosis corresponds to a diagnosis code that can be considered as an occupational disease. The system will not allow the physician to proceed without asking the patient's profession and recording/controlling such information in the relevant field. In case the patient's profession does not correspond to a risky occupation code in the list, the option "no" will be selected and the system will proceed with the normal operations. In case the patient's profession corresponds to a risky occupation code in the list, the option "yes" will be selected and the "occupation code" will be entered in the box appeared and then, the notice in the "procedural note" column for such code will be shown on the screen as follows. The physician will complete the process by informing the patient and the system will proceed with the normal operations. Occupational data of the patient will be sent to saglik.net online healthcare system within the patient's personal data set. If the disease is associated with the occupational diseases, this will be referred to the health boards of ministry of health occupational diseases hospitals, training and research hospitals and hospitals of state universities for issuance of a health board report. Based on this integration, the occupational skin diseases and their ICD codes and the occupational skin infections and their ICD codes are given in Table 47. (for details, go to http://www.who.int/occupational_ health/publications/en/oehicd10.pdf).

We conducted a survey in public hospitals, training and research hospitals and 12 dermatology clinics in state university hospitals in

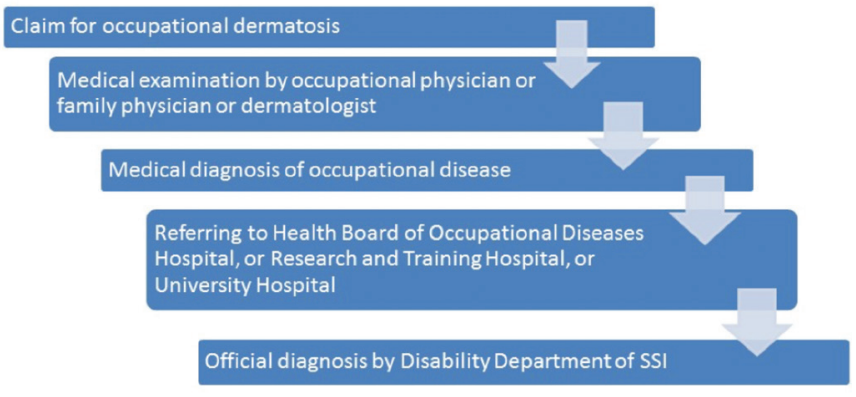

Figure 1. Diagnosis process for occupational diseases
İstanbul and found that only one of these clinics have occupational diseases communication system within their automation system and none of these hospitals can make referral to the health board. Therefore, this integration must be completed for diagnosis and referral to the health board during the first diagnosis stage of occupational dermatologic diseases. Three occupational diseases hospitals that exist in our country will not be able to remove this burden when it is thought that 100 thousand people per year have occupational skin diseases that should be diagnosed. In this instance, the health board report to be obtained from training and research hospitals and hospitals of state universities becomes even more important. Upon completion of abovementioned stages in the diagnostic process of occupational diseases, the said healthcare providers (public hospitals, research and training hospitals and state university hospitals) must report the cases they diagnosed as occupational disease to the SSI within ten days at the latest. Legal diagnosis of occupational diseases is established by the SSI. Diagnostic process of occupational diseases is shown in Figure 1. Some skin diseases, including pigmentation disorders such as hyperpigmentation and depigmentation, skin changes like collagenous, Raynaud's phenomenon, skin ulcerations, nail disorders, hair loss, sexually-transmitted diseases and melanoma, and airborne contact dermatitis are not regarded as occupational skin diseases in our country ${ }^{9}$. Thus, another necessity is to legally list these diseases as occupational diseases. Dermatologists do not have sufficient knowledge of definition of dermatologic diseases, necessity of communication of such diseases and the processes in the communication stage.

According to a questionnaire conducted in 151 dermatologists by Melikoğlu ${ }^{10}$, all dermatologists recognised eczema as an occupational skin disease, while sexually-transmitted diseases and skin cancers were regarded as occupational skin diseases by 112 (74.17\%) and 89 dermatologists (58.94\%), respectively.

In conclusion, there appear to be some problems with occupational diseases, their prevention, communication and statistics in our country. Effective protection programs require a multidimensional approach. Therefore, a common approach taken by the employees, employers, union representatives, safety engineers, and occupational physicians is important ${ }^{9}$. We believe that there is a need for many studies for diagnosis and prevention of occupational dermatologic diseases and a promising progress may be achieved by the verbal or written information studies and meetings to be conducted by the dermatology societies.

\section{Ethics}

Peer-review: Externally peer-reviewed.

\section{Authorship Contributions}

Concept: Ş.M., Design: Ş.M., Data Collection or Processing: Ş.M., Analysis or Interpretation: Ş.M., M.M., S.G., I.O.T., Literature Search: S.M., Writing: Ş.M.

Conflict of Interest: No conflict of interest was declared by the authors.

Financial Disclosure: The authors declared that this study received no financial support.

\section{References}

1. Akkurt i: Dünyada ve Ülkemizde Meslek Hastalıkları Tanı Sistemleri. Türk Tabipler Birliği Mesleki Sağlık ve Güvenlik Dergisi 2014;14:30-8. 
2. Canıvar C: Bir Olgu Üzerinden Türkiye'de Meslek Hastalıkları Tanı Sistemi Türk Tabipler Birliği Mesleki Sağlık ve Güvenlik Dergisi 2014;14:39-42.

3. ÇSGB Meslek Hastalıkları Rehberi Ankara 2011.

4. Saltık A: Ders Notları 2012. http://ahmetsaltik.net/arsiv/2012/05/Meslek_ hastaliklari1.pdf

5. Hapa A, Ersoy-Evans S: Mesleki Dermatozlar. Hacettepe Tip Dergisi 2011: 42:153-9.

6. ÇASGEM Meslek Hastalıkları Ankara 2013.

7. Ocaktan E: Meslek Hastalıkları. TC Sağlık Bakanlığı Halk Sağlı̆ı Kurumu " Çalışan Sağlığı ve Güvenliği Eğitimi ve Çalıştayı" Aralık 2014.
8. http://www.saglikaktuel.com/haber/meslek-hastaligi-tani-kodlarinin-ahbsve-hbys-sistemine-entegrasyonu-18567.htm

9. Arda F, Özşahin A: Kimyasal Maddelerle Oluşan Mesleki Deri Hastalıklar ve Korunma Yolları. Türk Tabipler Birliği Meslek Sağlığı ve Güvenliği Dergisi 2005;6:25-30.

10. Melikoğlu M: The Survey Results Relating To Occupational Diseases Carried Out By Dermatology and Venerology Doctors, Bildiri, P1078, 28 Eylül -02 Ekim 2016, 25. EADV kongresi, Viyana, Avusturya. 